\title{
A Revised ICD-10-CM Surveillance Case Definition for Injury-related Emergency Department Visits
}

by Holly Hedegaard, M.D., M.S.P.H., and Matthew F. Garnett, M.P.H., National Center for Health Statistics; and Renee L. Johnson, M.S.P.H., R.P.T., and Karen E. Thomas, M.P.H., National Center for Injury Prevention and Control

\section{Abstract}

Background -Administrative data from medical claims are often used for injury surveillance. Effective October 1, 2015, hospitals covered by the Health Insurance Portability and Accountability Act were required to use the International Classification of Diseases, 10th Revision, Clinical Modification (ICD-10-CM) to report medical information in administrative data. In 2017, the National Center for Health Statistics (NCHS) and the National Center for Injury Prevention and Control (NCIPC) published a proposed ICD-10-CM surveillance case definition for injuryrelated emergency department (ED) visits. At the time, ICD-10-CM coded data were not available for testing. When data became available, NCHS and NCIPC collaborated with the Council of State and Territorial Epidemiologists and epidemiologists from state and local health departments to test and update the proposed definition. This report summarizes the results and presents the 2021 revised ICD-10-CM surveillance case definition.

Methods - With guidance from NCHS and NCIPC, injury epidemiologists analyzed state-level ICD-10-CM-coded ED administrative data. The focus was on the subset of records that had an injury diagnosis code in any field other than the firstlisted diagnosis and no external cause-of-injury code. Characteristics of this subset were compared with those of records included in the 2017 proposed definition.

Results - Including the additional records from the subset would increase the total number of cases by $0.5 \%-1.7 \%$. Because the types of first-mentioned injury diagnoses in the subset were similar to those in records already included in the 2017 proposed definition, the definition was expanded to include the subset. In the 2021 revised definition, injury-related ED visits are defined as records with any of the selected ICD-10-CM S, T, O, and M diagnosis codes, or any of the selected V, W, X, and Y external cause-of-injury codes, in any diagnosis or external cause-of-injury field.

Conclusions - The revised ICD-10-CM surveillance case definition for injuryrelated ED visits provides standardized selection criteria for consistency in identifying cases across populations and over time.

Keywords: injury surveillance $\bullet$ injury morbidity $\bullet$ nonfatal injury $\bullet$ administrative claims data

\section{Introduction}

To ensure consistency in identifying injuries and monitoring trends, the National Center for Health Statistics (NCHS) and the National Center for Injury Prevention and Control (NCIPC) at the Centers for Disease Control and Prevention have frequently collaborated with injury surveillance and epidemiology partners to develop standard case definitions and reporting frameworks for injury surveillance (1-10). Surveillance case definitions provide uniform criteria for selecting cases, which allows for comparison of results across different data sets and over time (11). Recommended surveillance case definitions for injury hospitalizations and injury-related emergency department (ED) visits have been in use for nearly 2 decades $(3,4)$.

In the United States, surveillance of injury hospitalizations and injuryrelated ED visits is often conducted using administrative data from medical claims or billing processes. Claims are submitted by health care providers to public and private payers through the universal billing form (UB-04), and they include billing codes that reflect a patient's medical conditions and symptoms as well as services and procedures

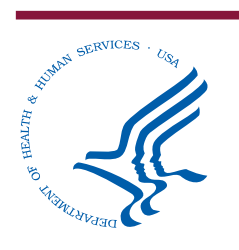


received (12). Before October 1, 2015, health care providers used billing codes from the International Classification of Diseases, Ninth Revision, Clinical Modification (ICD-9-CM) to report clinical information. Effective October 1, 2015, the U.S. Department of Health and Human Services required all hospitals and health care providers covered by the Health Insurance Portability and Accountability Act to transition to the International Classification of Diseases, 10th Revision, Clinical Modification (ICD-10-CM) for reporting medical information in administrative transactional data $(13,14)$. As a result of this transition, existing ICD-9-CMbased injury surveillance case definitions and reporting frameworks needed to be updated to reflect the new ICD-10-CM coding system.

In 2017, NCHS and NCIPC published a proposed surveillance case definition for injury-related ED visits based on ICD-10-CM (1). A detailed description of the development of the proposed definition is published elsewhere (1) and briefly summarized here.

The 2017 proposed ICD-10-CM surveillance case definition for injuryrelated ED visits was developed to reflect codes and selection criteria similar to those in the ICD-9-CM surveillance case definition (4). To identify comparable ICD-10-CM injury diagnosis and external cause-of-injury codes, NCHS and NCIPC researchers applied General Equivalence Mappings (GEMs) to the ICD-9-CM surveillance case definition. GEMs, developed by NCHS and the Centers for Medicare \& Medicaid Services (CMS), help translate between different versions of the ICD clinical modification (15). The relevant injury diagnosis and external cause codes included in the proposed definition are shown in Table A.

A new feature in ICD-10-CM, not found in ICD-9-CM, is the presence of a 7 th character in the ICD-10-CM code that indicates the type of encounter when either the diagnosis is made or the external cause code is assigned. A 7th character of A, B, or C in the injury diagnosis code indicates an initial encounter for active treatment of the condition; a character of $\mathrm{D}$ through $\mathrm{R}$ indicates a subsequent encounter for routine care of the condition during the healing or recovery phase; and a character of $\mathrm{S}$ indicates sequelae from a previous injury, meaning complications or conditions that arise as a direct result of a past injury (14). For external cause codes, the 7th characters are A for initial encounter, $\mathrm{D}$ for subsequent encounter, and $\mathrm{S}$ for sequelae. Because the ICD-9$\mathrm{CM}$ definition did not include sequelae from a previous injury, for comparability, the 2017 proposed ICD-10-CM surveillance definition for injury-related ED visits included only diagnosis codes with a 7th character of $A$ through $R$ or missing a 7th character, or an external cause code with a 7th character of A or $\mathrm{D}$ or missing a 7 th character - that is, codes indicating an initial or subsequent encounter only (1). Codes with a 7th character of S, indicating that the visit was for treatment of sequelae from a previous injury, were not included in the case selection criteria.

As with the ICD-9-CM definition, the 2017 proposed ICD-10-CM definition had two primary selection criteria (1). An ED visit was considered to be injury-related if either: (a) the firstlisted diagnosis code indicated an injury diagnosis (nature-of-injury) code, or (b) an external cause code had been assigned in any field on the record.

At the time the 2017 proposed definition was developed, ICD-10-CM coded data on ED visits were not readily available, so the proposed surveillance definition could not be tested. As ICD-10-CM coded data became available, NCHS and NCIPC collaborated with the Council of State and Territorial Epidemiologists and several state and local health departments to test the proposed definition. The testing focused on three core questions:

1. Should any additional ICD-10-CM codes be included in the injury surveillance case definition?

2. Should the case definition be limited to initial encounters only?

3. Should the case definition for injuryrelated ED visits be expanded to include records with any mention of an injury diagnosis code, that is, not require that the injury diagnosis code be the first-listed diagnosis?

The first two core questions were addressed in a study that tested the proposed ICD-10-CM surveillance case definition for injury hospitalizations.

Table A. ICD-10-CM nature-of-injury and external cause-of-injury codes in the 2017 proposed surveillance case definition for injury-related emergency department visits

ICD-10-CM nature-of-injury code ${ }^{1,2}$ Type of injury

\begin{tabular}{|c|c|}
\hline All $S$ codes & Anatomic injuries \\
\hline T07-T34 $\ldots \ldots \ldots \ldots \ldots \ldots \ldots \ldots$ & Foreign bodies, burns, corrosions, frostbite \\
\hline $\begin{array}{l}\text { T36-T50 with a } 6 \text { th character of } 1,2,3 \text {, or } 4 \\
\text { (Exceptions: T36.9, T37.9, T39.9, T41.4, } \\
\text { T42.7, T43.9, T45.9, T47.9, and T49.9, which } \\
\text { are included if the code has a 5th character }\end{array}$ & \\
\hline of $1,2,3$, or 4$) \ldots \ldots \ldots \ldots \ldots \ldots$ & Drug poisoning (excludes adverse effects and underdosing) \\
\hline T51-T65 $\ldots \ldots \ldots \ldots \ldots \ldots \ldots \ldots$ & Toxic effects of substances nonmedicinal as to source \\
\hline T66-T76 & $\begin{array}{l}\text { Other and unspecified effects of external causes (such as } \\
\text { radiation, heat, light, hypothermia, hyperthermia, asphyxiation, } \\
\text { child and adult abuse, lightning, drowning, or motion sickness) }\end{array}$ \\
\hline T79 & Certain early complications of trauma, not elsewhere classified \\
\hline
\end{tabular}

ICD-10-CM external cause-of-injury code ${ }^{1,2}$ Type of external cause of injury

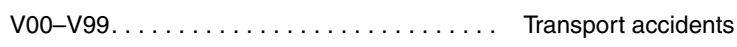

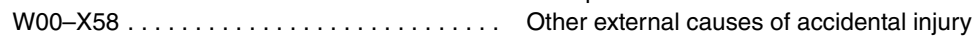

$\mathrm{X} 71-\mathrm{X} 83 \ldots \ldots \ldots \ldots \ldots \ldots \ldots \ldots \ldots \ldots \ldots \ldots \ldots$ Intentional self-harm

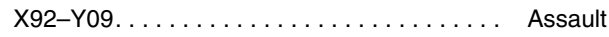

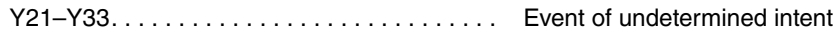

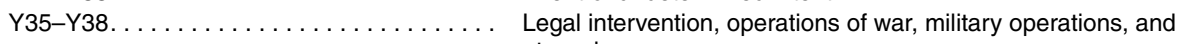
terrorism

${ }^{1}$ An emergency department visit is considered injury-related if either: (a) the first-listed diagnosis code indicates an injury diagnosis or (b) an external cause-of-injury code is assigned to the record.

${ }^{2}$ Contains any 7 th character except $\mathrm{S}$ (sequelae from previous injury). T30-T32 do not have a 7th character.

NOTE: ICD-10-CM is the International Classification of Diseases, 10th Revision, Clinical Modification.

SOURCE: Hedegaard HB, Johnson RL, Ballesteros MF. Proposed ICD-10-CM surveillance case definitions for injury hospitalizations and emergency department visits. National Health Statistics Reports; no 100. Hyattsville, MD: National Center for Health Statistics. 2017. Available from: https://www.cdc.gov/nchs/data/nhsr/NHSR100.pdf. 
The results from that study have been described in detail elsewhere (2) and are briefly summarized here. The decisions made for the first two core questions based on results from the injury hospitalization study were also adopted in the revision of the ICD-10-CM surveillance case definition for injuryrelated ED visits described in this report.

In response to the first question about including additional diagnosis codes, several ICD-10-CM codes were added to the selection criteria for injury hospitalizations and ED visits. These include:

- O9A.2, Injury, poisoning and certain other consequences of external causes complicating pregnancy, childbirth and the puerperium.

- O9A.3, Physical abuse complicating pregnancy, childbirth and the puerperium.

- O9A.4, Sexual abuse complicating pregnancy, childbirth and the puerperium.

- O9A.5, Psychological abuse complicating pregnancy, childbirth and the puerperium.

- T84.04 (replaced by M97), Periprosthetic fracture around internal prosthetic joint. In the federal fiscal year 2017 version of ICD-10-CM, effective October 1, 2016, T84.04 codes were deleted and replaced by M97 codes (16). Both T84.04 (before October 1, 2016) and M97 (October 1, 2016, and later) are included in the revised ICD-10-CM surveillance case selection criteria.

In response to the second question on limiting the selection criteria to initial encounters only, the proposed definition (which included both initial and subsequent encounters) was modified to include only records that reflect an initial encounter for active treatment of the injury or that lacked information on encounter type (2).

The third core question is the focus of this National Health Statistics Report-whether to expand the ICD-10-CM surveillance case definition for injury-related ED visits to include records with any mention of an injury diagnosis code, that is, not require that the injury diagnosis code be the firstlisted diagnosis. The Figure diagrams the components of the 2017 proposed definition as well as the types of records that would be added if the proposed definition was revised. ED visit records are categorized as to whether they have an injury diagnosis code (and if so, whether the injury code is listed as the first diagnosis or in a subsequent field), and whether they have an external cause-of-injury code. In the Figure, Cells B, C, D, and F represent the criteria for including a record as an injury-related ED visit using the 2017 proposed surveillance case definition. Cell E represents the subset of records that would be added in the possible modification, that is, records that: (a) had an injury diagnosis code in any field other than the first-listed diagnosis, meaning that the injury diagnosis code was in a subsequent field, and (b) did not have an external cause-of-injury code.

This report summarizes all modifications made to the proposed definition and presents the final 2021 revised ICD-10-CM surveillance case definition for identifying injury-related ED visits when using administrative billing data.

\section{Methods}

With guidance from NCHS and NCIPC, injury epidemiologists from four jurisdictions analyzed state or local

Figure. Possible modification to the inclusion criteria of the 2017 proposed ICD-10-CM surveillance case definition for injury-related emergency department visits

\begin{tabular}{|c|c|c|}
\hline \multirow[b]{2}{*}{$\begin{array}{c}\text { Does the record have an } \\
\text { injury diagnosis code? }\end{array}$} & \multicolumn{2}{|c|}{$\begin{array}{l}\text { Possible addition to the } 2017 \text { definition } \\
\text { Does the record have an external } \\
\text { cause-of-injury code? }\end{array}$} \\
\hline & No & Yes \\
\hline No & $A$ & B \\
\hline Yes, in the first-listed diagnosis field & C & D \\
\hline $\begin{array}{l}\text { Yes, in a subsequent (not first-listed) } \\
\text { diagnosis field }\end{array}$ & $E$ & $F$ \\
\hline \multicolumn{3}{|c|}{$\begin{array}{l}\text { NOTES: Cells B, C, D, and F represent the criteria for including a record as an injury-related emergency department visit } \\
\text { in the } 2017 \text { proposed surveillance case definition. In the possible modification, Cell E would be added to the inclusion } \\
\text { criteria. The injury diagnosis and external cause-of-injury codes referred to in the Figure are those listed in Table A of this } \\
\text { report. } \\
\text { SOURCES: National Center for Health Statistics and National Center for Injury Prevention and Control. }\end{array}$} \\
\hline
\end{tabular}

ICD-10-CM-coded ED administrative claims data based on the UB-04 form (12). Records for possible injury-related ED visits were identified using the injury diagnosis and external cause codes shown in Table A.

The focus of the analysis was an exploration of the subset of records in Cell E of the Figure, that is, records that had an injury diagnosis code in a subsequent field and did not have an external cause code. This subset of records was not included in the 2017 proposed definition nor in the ICD-9-CM surveillance case definitions for injury-related ED visits. The Cell E subset was examined to determine: (a) the types of noninjury diagnoses found in the first-listed diagnosis field, and (b) the types of injury diagnoses first found in a field other than the first-listed diagnosis. These characteristics of the Cell E subset were compared with those of records included in the 2017 ICD-10-CM proposed definition, in particular Cells $\mathrm{C}$ and $\mathrm{F}$ (Figure). Cells $\mathrm{C}$ and $\mathrm{E}$ are similar in that they both include records that do not have external cause codes, but they differ in that an injury diagnosis code is the first-listed diagnosis for records in Cell $\mathrm{C}$ but not the first-listed diagnosis for records in Cell E. Cells E and F are similar in that they both include records where the injury diagnosis is found in a subsequent field, that is, not the firstlisted diagnosis, but they differ in that 
records in Cell $\mathrm{E}$ do not have an external cause code while records in Cell $\mathrm{F}$ do.

If the types of noninjury diagnoses found in the first-listed diagnosis field were similar for Cells E and F, and the types of first-mentioned injury diagnoses were similar in Cells $\mathrm{E}$ and $\mathrm{F}$ and in Cells $\mathrm{E}$ and $\mathrm{C}$, then it would be reasonable to expand the case definition to include the Cell E subset.

\section{Results}

Analysis of ICD-10-CM-coded data showed that expanding the case definition to include records in Cell $\mathrm{E}$ of the Figure (specifically, records that had an injury diagnosis code in a subsequent field and did not have an external cause code) would increase the total number of injury-related ED visit cases by $0.5 \%-1.7 \%$.

For records in the Cell E subset, the first-listed diagnosis was most frequently from ICD-10-CM chapters for mental, behavioral and neurodevelopmental disorders (F01-F99) ( $10 \%-25 \%$, depending on jurisdiction); diseases of the musculoskeletal system and connective tissue (M00-M99) (14\%-22\%); and symptoms, signs and abnormal clinical and laboratory findings, not elsewhere classified (R00-R99) (16\%-29\%). This pattern was similar to that found with records in the Cell F subset $(16 \%-22 \%, 16 \%-19 \%$, and $25 \%-30 \%$ of the Cell $\mathrm{F}$ subset, respectively). For both Cells E and F, the injury diagnosis code was listed as the second or third diagnosis for $90 \%$ of the records.

Table B shows the most frequent first-mentioned injury diagnoses in Cells E, F, and C. Six of the eight most frequent first-mentioned injury diagnoses in Cells $\mathrm{E}$ and $\mathrm{F}$ were the same and appeared with similar frequency: S00, superficial injury of the head; S01, open wound of the head; $\mathrm{S} 02$, fracture of skull and facial bones; S09, other and unspecified injuries of the head; S39, other and unspecified injuries of abdomen, lower back, pelvis and external genitalia; and T14, injury of unspecified body region. The two most frequent diagnoses found in Cell $\mathrm{F}$ but not among the most frequent diagnoses in Cell $\mathrm{E}$ were S60, superficial injury of wrist, hand and fingers; and S80, superficial injury of knee and lower leg.

Five of the eight most frequent first-mentioned injury diagnoses in Cells $\mathrm{E}$ and $\mathrm{C}$ were the same: S00, superficial injury of the head; S01, open wound of the head; S09, other and unspecified injuries of the head; S39, other and unspecified injuries of abdomen, lower back, pelvis and external genitalia; and S61, open wound of wrist, hand and fingers (Table B). The three most frequent diagnoses found in Cell $\mathrm{C}$ but not among the most frequent diagnoses in Cell $\mathrm{E}$ were codes for dislocation or sprain of the wrist and hand (S63), the knee (S83), and the ankle, foot and toe (S93).

Because many of the most frequent first-mentioned injury diagnoses in Cell $\mathrm{E}$ were similar to those in Cells $\mathrm{C}$ and $\mathrm{F}$-whose subsets were already included in the 2017 proposed surveillance case definition for injury-related ED visitsthe decision was made to expand the 2017 proposed definition to include the Cell E subset.

\section{Revised Surveillance Case Definition}

Results from this analysis and the earlier study noted in the Introduction (2) were used to revise the 2017 proposed ICD-10-CM surveillance case definition for injury-related ED visits. In the 2021 revised definition, an injury-related ED visit is defined as an ED record with any mention of an ICD-10-CM injury diagnosis (nature-of-injury) or external cause code listed in Table $\mathrm{C}$ with a 7th character indicating an initial encounter (A, B, or C for injury diagnosis codes and A for external cause codes) or that is missing a 7 th character.

Table B. Most frequent first-mentioned ICD-10-CM injury diagnosis codes for records in Figure cells E, F, and C

\begin{tabular}{|c|c|c|c|c|c|c|c|c|}
\hline \multicolumn{3}{|c|}{ Cell $E^{1}$} & \multicolumn{3}{|c|}{ Cell $F^{1}$} & \multicolumn{3}{|c|}{ Cell $C^{1}$} \\
\hline Code $^{2}$ & Description & $\begin{array}{l}\text { Percent of } \\
\text { records }^{3}\end{array}$ & Code $^{2}$ & Description & $\begin{array}{l}\text { Percent of } \\
\text { records }^{3}\end{array}$ & Code $^{2}$ & Description & $\begin{array}{l}\text { Percent of } \\
\text { records }\end{array}$ \\
\hline Soo & Superficial injury of head . . . . . . . & $5-12$ & Soo & Superficial injury of head . . . . . . . & $10-11$ & So0 & Superficial injury of head . . . . . . . & 3 \\
\hline S01 & Open wound of head $\ldots \ldots \ldots \ldots$ & $5-8$ & S01 & Open wound of head $\ldots \ldots \ldots \ldots$ & $5-7$ & S01 & Open wound of head $\ldots \ldots \ldots \ldots$ & 6 \\
\hline S02 & $\begin{array}{l}\text { Fracture of skull and } \\
\text { facial bones } \ldots \ldots \ldots \ldots \ldots\end{array}$ & $2-4$ & S02 & $\begin{array}{l}\text { Fracture of skull and } \\
\text { facial bones } \ldots \ldots \ldots\end{array}$ & $2-3$ & So9 & $\begin{array}{l}\text { Other and unspecified injuries of } \\
\text { head } \ldots \ldots \ldots \ldots \ldots \ldots \ldots \ldots\end{array}$ & $3-5$ \\
\hline S09 & $\begin{array}{l}\text { Other and unspecified } \\
\text { injuries of head. ........... }\end{array}$ & $4-5$ & So9 & $\begin{array}{l}\text { Other and unspecified } \\
\text { injuries of head..... }\end{array}$ & $8-9$ & S39 & $\begin{array}{l}\text { Other and unspecified injuries of } \\
\text { abdomen, lower back, pelvis and } \\
\text { external genitalia } \ldots \ldots \ldots \ldots \ldots\end{array}$ & $5-6$ \\
\hline S39 & $\begin{array}{l}\text { Other and unspecified injuries of } \\
\text { abdomen, lower back, pelvis and } \\
\text { external genitalia } \ldots \ldots \ldots \ldots \ldots\end{array}$ & 6 & S39 & $\begin{array}{l}\text { Other and unspecified injuries of } \\
\text { abdomen, lower back, pelvis and } \\
\text { external genitalia } \ldots \ldots \ldots \ldots \ldots\end{array}$ & 4 & S61 & $\begin{array}{l}\text { Open wound of wrist, hand and } \\
\text { fingers. } \ldots \ldots \ldots \ldots \ldots \ldots \ldots\end{array}$ & $4-5$ \\
\hline S61 & $\begin{array}{l}\text { Open wound of wrist, hand and } \\
\text { fingers. } \ldots \ldots \ldots \ldots \ldots \ldots \ldots\end{array}$ & $2-5$ & S60 & $\begin{array}{l}\text { Superficial injury of wrist, hand and } \\
\text { fingers. } \ldots \ldots \ldots \ldots \ldots \ldots\end{array}$ & $2-4$ & S63 & $\begin{array}{l}\text { Dislocation and sprain of } \\
\text { wrist and hand } \ldots \ldots \ldots \ldots \ldots\end{array}$ & $3-4$ \\
\hline S90 & $\begin{array}{c}\text { Superficial injury of ankle, foot and } \\
\text { toes. . } \ldots \ldots \ldots \ldots \ldots \ldots \ldots \ldots\end{array}$ & $2-3$ & $\mathrm{~S} 80$ & $\begin{array}{l}\text { Superficial injury of knee and lower } \\
\text { leg. } \ldots \ldots \ldots \ldots \ldots \ldots \ldots \ldots\end{array}$ & $4-5$ & S83 & Dislocation and sprain of knee. . . . & $4-5$ \\
\hline T14 & $\begin{array}{l}\text { Injury of unspecified body } \\
\text { region } \ldots \ldots \ldots \ldots \ldots \ldots \ldots\end{array}$ & $3-7$ & $\mathrm{~T} 14$ & $\begin{array}{l}\text { Injury of unspecified body } \\
\text { region } \ldots \ldots \ldots \ldots \ldots \ldots \ldots\end{array}$ & $3-4$ & S93 & $\begin{array}{l}\text { Dislocation and sprain at ankle, } \\
\text { foot and toe. . . . . . . . } \ldots \ldots\end{array}$ & $10-15$ \\
\hline
\end{tabular}

${ }^{1}$ Cell $\mathrm{E}$ includes records with an injury diagnosis code in a subsequent field and no external cause-of-injury code; Cell $\mathrm{F}$ includes records with an injury diagnosis code in a subsequent field and an external cause-of-injury code; and Cell $C$ includes records with an injury diagnosis code as the first-listed diagnosis and no external cause-of-injury code; see Figure in this report.

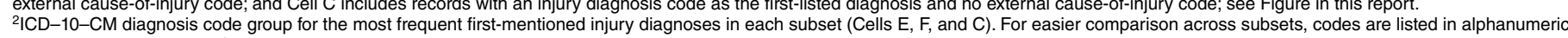
order, not by percentage of records.

${ }^{3}$ Range reflects variation in percentage by jurisdiction.

NOTE: ICD-10-CM is the International Classification of Diseases, 10th Revision, Clinical Modification.

SOURCES: National Center for Health Statistics and National Center for Injury Prevention and Control. 
Table C. ICD-10-CM nature-of-injury and external cause-of-injury codes in the 2021 revised ICD-10-CM surveillance case definition for injury-related emergency department visits

\begin{tabular}{|c|c|}
\hline ICD-10-CM nature-of-injury code ${ }^{1,2}$ & Type of injury \\
\hline All $S$ codes ...... & Anatomic injuries \\
\hline T07-T34 $\ldots \ldots \ldots \ldots \ldots \ldots \ldots \ldots$ & Foreign bodies, burns, corrosions, frostbite \\
\hline $\begin{array}{l}\text { T36-T50 with a 6th character of } 1,2,3 \text {, or } 4 \\
\text { (Exceptions: T36.9, T37.9, T39.9, T41.4, } \\
\text { T42.7, T43.9, T45.9, T47.9, and T49.9, which } \\
\text { are included if the code has a 5th character } \\
\text { of } 1,2,3 \text {, or } 4 \text { ) } \ldots \ldots \ldots \ldots \ldots \ldots \ldots \ldots\end{array}$ & Drug poisoning (excludes adverse effects and underdosing) \\
\hline T51-T65 $\ldots \ldots \ldots \ldots \ldots \ldots \ldots \ldots$ & Toxic effects of substances nonmedicinal as to source \\
\hline T66-T76 & $\begin{array}{l}\text { Other and unspecified effects of external causes (such as } \\
\text { radiation, heat, light, hypothermia, hyperthermia, asphyxiation, } \\
\text { child and adult abuse, lightning, drowning, or motion sickness) }\end{array}$ \\
\hline T79 ..... & Certain early complications of trauma, not elsewhere classified \\
\hline O9A.2-O9A.5. & $\begin{array}{l}\text { Injury, poisoning, and certain other consequences of external } \\
\text { causes, and physical, sexual and psychological abuse, } \\
\text { complicating pregnancy, childbirth and the puerperium }\end{array}$ \\
\hline T84.04 & Periprosthetic fracture around internal prosthetic joint \\
\hline$M 97^{3} \ldots$ & Periprosthetic fracture around internal prosthetic joint \\
\hline
\end{tabular}

ICD-10-CM external cause-of-injury code cot, $^{10}$

Type of external cause of injury

V00-V99................. Transport accidents

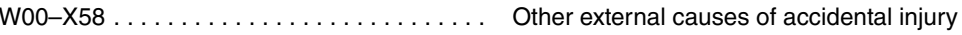

$\mathrm{X} 71-\mathrm{X} 83 \ldots \ldots \ldots \ldots \ldots \ldots \ldots \ldots$ Intentional self-harm

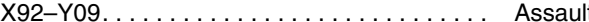

Y21-Y33. . . . . . . . . . . . . . . Event of undetermined intent

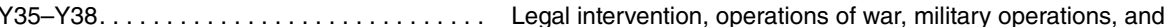
terrorism

${ }^{1}$ An emergency department visit is considered injury-related if either: (a) one of the listed injury diagnosis codes or (b) one of the listed external cause-of-injury codes is assigned to the record in any field.

${ }^{2}$ Code must have 7 th character of A, B, C, or missing (as in, initial encounters or missing information on encounter type). T30-T32 do not have a 7 th character.

${ }^{3}$ T84.04 was replaced by M97 in the federal fiscal year 2017 version of ICD-10-CM, which became effective on October 1, 2016. ${ }^{4}$ Code must contain 7 th character of A or missing.

NOTE: ICD-10-CM is the International Classification of Diseases, 10th Revision, Clinical Modification.

SOURCES: National Center for Health Statistics and National Center for Injury Prevention and Control.

The 2021 revised ICD-10-CM

surveillance case definition for injuryrelated ED visits varies from the 2017 proposed definition in several ways:

- The list of ICD-10-CM codes in the revised definition is expanded by the addition of O9A.2-O9A.5, Injuries complicating pregnancy, childbirth and the puerperium; and T84.04 and M97, Periprosthetic fracture around internal prosthetic joint (Table C).

- The revised case definition is limited to ED visits for initial encounters only or visits missing information on encounter type - that is, visits do not include records for subsequent encounters for routine follow-up care or for sequelae from previous injuries.

- The selection criteria in the revised definition have been expanded to include records with any mention of an injury diagnosis code or external cause code listed in Table $\mathrm{C}$.

\section{Discussion}

Standard surveillance case definitions are routinely used to make it easier to compare case counts and rates across jurisdictions and over time $(4,11)$. In 2017, a proposed ICD-10-CM surveillance case definition for injuryrelated ED visits was published (1). However, at the time the definition was developed, ICD-10-CM-coded ED data were not readily available to test the proposed selection criteria. This report describes the results from testing the proposed definition using ICD-10-CMcoded administrative data and, based on the findings, provides a revised surveillance definition.

Expansion of the selection criteria to include records in the Cell E subset (records that have an injury diagnosis code in a subsequent field and do not have an external cause code) (Figure) will result in an increase in the number of injury-related ED visit cases. Data sets with less complete external cause coding - that is, data sets with a higher proportion of records in Cell $\mathrm{E}$ than in Cell F (Figure) - will have a larger percentage increase in the total number of injury-related ED visits than data sets with a lower proportion of records in Cell E than in Cell F. However, because records in the Cell E subset do not have an external cause-of-injury code, they cannot be categorized by mechanism and intent of injury other than for poisoning, asphyxiation, and certain mechanisms identified from $\mathrm{T}$ codes (5).

As with the ICD-9-CM surveillance case definition for injury-related ED visits, the ICD-10-CM definition reflects use of ED visits for possible injury. The selection criteria for both the ICD-9-CM definition and the ICD-10-CM definition include records that have an external cause code, even in the absence of an injury diagnosis code (Cell B of Figure). Often, patients arrive at the ED after being involved in an injury event such as a motor vehicle crash or fall, but when evaluated, they are found not to have sustained an anatomic or physiologic injury. For prevention purposes, public health practitioners are often interested in identifying persons who were involved in an injury event, whether an injury diagnosis is made or not. For this reason, records with an external cause code are included in the recommended surveillance case definition, regardless of whether an injury diagnosis code is present.

Despite case selection criteria based on the same list of injury diagnosis codes, the ICD-10-CM surveillance case definition for injury-related ED visits differs from the ICD-10-CM surveillance case definition for injury hospitalizations in two key ways (2). First, the revised definition for injuryrelated ED visits includes records with any mention of an injury diagnosis (the injury diagnosis does not need to be the first-listed diagnosis), whereas the injury hospitalization definition includes only records with a principal diagnosis of an injury. For injury hospitalizations, the surveillance case definition is meant to reflect hospitalizations for which care of the injury is a significant contributor to the reason for the hospitalization. For this reason, case selection is based on a principal diagnosis of injury. The ED case definition is more expansive and 
includes records with any mention of an injury diagnosis. Second, as noted earlier, the selection criteria for the surveillance case definition for injury-related ED visits include records with any mention of an external cause code, regardless of whether an injury diagnosis code is present. The surveillance case definition for injury hospitalizations is based on a principal diagnosis of injury, while the presence of an external cause code alone is not sufficient for inclusion as an injury hospitalization (2).

In using the revised definition, researchers and epidemiologists should consider that:

- The revised ED surveillance case definition was developed for use with data from administrative claims based on the UB-04 form. The selection criteria in this surveillance definition may not be directly applicable to other data sets often used for injury morbidity surveillance, such as data from prehospital care (emergency medical services reports), outpatient visits, or syndromic surveillance systems. Before applying these selection criteria to other data sources, testing and validation should be conducted to determine whether the definition needs to be adapted for use with other data sets.

- The ICD-10-CM surveillance case definition for injury-related ED visits was developed for use in public health surveillance to study trends in a population and should not be used as a clinical case definition for an individual patient.

- The 2021 revised ICD-10-CM surveillance case definition for injury-related ED visits, which includes records with any mention of select injury diagnosis and external cause codes, differs from the ICD-9-CM definition. The ICD-9-CM definition included records with any mention of select external cause codes or for which the first-listed diagnosis is an injury diagnosis. Additionally, ICD-9-CM did not have distinct codes to identify the type of encounter (initial, subsequent, or sequelae) when the diagnosis or external cause code was assigned. Because the inclusion criteria differ, trend analysis using the ICD-9-CM definition for some years and the ICD-10-CM definition for other years is not recommended without significant additional analysis and a clear understanding of issues that might contribute to any changes observed.

- Each year, NCHS and CMS update the ICD-10-CM code set to add or delete codes, revise descriptions, modify notes on inclusion and exclusion, and make other adjustments as needed. Because the ICD-10-CM code set is updated annually, the ICD-10-CM surveillance case definition for injury-related ED visits will need to be continually updated to address any relevant changes to the ICD-10-CM codes. Users are advised to check the NCHS Injury Data and Resources, Tools and Frameworks website (available from: https://www.cdc.gov/nchs/ injury/injury_tools.htm) for the most current recommendations.

- The performance of the revised ICD-10-CM surveillance case definition for injury-related $E D$ visits should continue to be monitored, and the selection criteria adjusted if needed, to address any limitations identified.

\section{Conclusion}

The 2021 revised ICD-10-CM surveillance case definition for injuryrelated $E D$ visits provides standard criteria for selecting records in which a possible or confirmed injury contributed to the reason for the ED visit. The definition provides a uniform standard enabling the use of ICD-10-CM-coded data to study differences in injury-related ED visits among different populations and over time. Additional tools such as injury matrices $(5,6)$ can be used to further characterize injury-related ED visits by intent and mechanism of injury or by body region and nature of injury.

\section{References}

1. Hedegaard HB, Johnson RL, Ballesteros MF. Proposed ICD-10-CM surveillance case definitions for injury hospitalizations and emergency department visits. National Health Statistics Reports; no 100. Hyattsville, MD: National Center for Health Statistics. 2017. Available from: https://www.cdc.gov/nchs/data/ nhsr/NHSR100.pdf.

2. Hedegaard H, Johnson RL. An updated International Classification of Diseases, 10th Revision, Clinical Modification (ICD-10-CM) surveillance case definition for injury hospitalizations. National Health Statistics Reports; no 125. Hyattsville, MD: National Center for Health Statistics. 2019. Available from: https://www.cdc.gov/nchs/data/nhsr/ nhsr125-508.pdf.

3. State and Territorial Injury Prevention Directors Association, Injury

Surveillance Workgroup. Consensus recommendations for using hospital discharge data for injury surveillance. Marietta, GA. 2003. Available from: https://cdn.ymaws.com/www. safestates.org/resource/resmgr/ imported/HospitalDischargeData.pdf.

4. State and Territorial Injury Prevention Directors Association, Injury Surveillance Workgroup. Consensus recommendations for injury surveillance in state health departments. Marietta, GA. 2007. Available from: https://cdn.ymaws. com/www.safestates.org/resource/ resmgr/imported/ISW5\%20Final\%20 9.13.07\%20(color).pdf.

5. Hedegaard H, Johnson RL, Garnett MF, Thomas KE. The International Classification of Diseases, 10th Revision, Clinical Modification (ICD-10-CM) external cause-ofinjury framework for categorizing mechanism and intent of injury. National Health Statistics Reports; no 136. Hyattsville, MD: National Center for Health Statistics. 2019. Available from: https://www.cdc.gov/nchs/data/ nhsr/nhsr136-508.pdf.

6. Hedegaard H, Johnson RL, Garnett MF, Thomas KE. The 2020 International Classification of Diseases, 10th Revision, Clinical 
Modification injury diagnosis framework for categorizing injuries by body region and nature of injury. National Health Statistics Reports; no 150. Hyattsville, MD: National Center for Health Statistics. 2020. Available from: https:/www.cdc.gov/nchs/data/ nhsr/nhsr150-508.pdf.

7. Annest JL, Hedegaard H, Chen LH, Warner M, Smalls E. Proposed framework for presenting injury data using ICD-10-CM external cause of injury codes. Atlanta, GA: National Center for Injury Prevention and Control, National Center for Health Statistics. 2014. Available from: https://www.cdc.gov/injury/wisqars/ pdf/ICD-10-CM_External_Cause_ Injury_Codes-a.pdf.

8. Hedegaard H, Johnson RL, Warner M, Chen LH, Annest JL. Proposed framework for presenting injury data using the International Classification of Diseases, 10th Revision, Clinical Modification diagnosis codes. National Health Statistics Reports; no 89. Hyattsville, MD: National Center for Health Statistics. 2016. Available from: https:/www.cdc.gov/nchs/data/ nhsr/nhsr089.pdf.

9. Fingerhut LA, Warner M. The ICD10 injury mortality diagnosis matrix. Inj Prev 12(1):24-9. 2006.

10. Barell V, Aharonson-Daniel L, Fingerhut LA, Mackenzie EJ, Ziv A, Boyko V, et al. An introduction to the Barell body region by nature of injury diagnosis matrix. Inj Prev 8(2):91-6. 2002.

11. Crosby AE, Ortega L, Melanson C. Self-directed violence surveillance: Uniform definitions and recommended data elements (Version 1.0). Atlanta, GA: National Center for Injury Prevention and Control. 2011. Available from: https://www.cdc.gov/ violenceprevention/pdf/self-directedviolence-a.pdf.

12. American Hospital Association. Official UB-04 data specifications manual 2022. 2021. Available from: https://ebooks.aha.org/1jp9jcc?start BookmarkIdx $=200$.

13. Centers for Medicare \& Medicaid Services. International classification of diseases, 10th revision (ICD-10). Baltimore, MD. Available from:
https://www.cms.gov/Medicare/ Coding/ICD10/index.html.

14. National Center for Health Statistics. International classification of diseases, 10th revision, clinical modification (ICD-10-CM). Hyattsville, MD. Available from: https://www.cdc.gov/nchs/icd/ icd $10 \mathrm{~cm} . h \mathrm{tm}$.

15. Centers for Medicare \& Medicaid Services. General equivalence mappings: ICD-9-CM to and from ICD-10-CM and ICD-10-PCS. Baltimore, MD. 2009. Available from: https://www.cms.gov/Medicare/ Coding/ICD10/downloads/ICD-10_ GEM_fact_sheet.pdf.

16. Centers for Disease Control and Prevention. ICD-10-CM Coordination and Maintenance Committee meeting, diagnosis agenda. September 18-19, 2013. Available from: https://www.cdc. gov/nchs/data/icd/icd_topic_packet_ sept_181913.pdf. 


\section{U.S. DEPARTMENT OF HEALTH \& HUMAN SERVICES}

FIRST CLASS MAIL

POSTAGE \& FEES PAID $\mathrm{CDC} / \mathrm{NCHS}$

Centers for Disease Control and Prevention PERMIT NO. G-284

National Center for Health Statistics

3311 Toledo Road, Room 4551, MS P08

Hyattsville, MD 20782-2064

OFFICIAL BUSINESS

PENALTY FOR PRIVATE USE, $\$ 300$

For more NCHS NHSRs, visit:

https://www.cdc.gov/nchs/products/nhsr.htm.

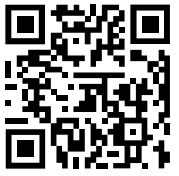

\section{Acknowledgments}

The authors would like to acknowledge the contributions of the Council of State and Territorial Epidemiologists and injury epidemiologists from state and local health departments, particularly from Massachusetts, New Jersey, New York state, and Southern Nevada Health District, for their assistance with data analysis, interpretation, and discussion of the findings in preparing the 2021 revised ICD-10-CM surveillance case definition for injury-related emergency department visits.

\section{Suggested citation}

Hedegaard H, Garnett MF, Johnson $\mathrm{RL}$, Thomas KE. A revised ICD-10-CM surveillance case definition for injury-related emergency department visits. National Health Statistics Reports; no 164. Hyattsville, MD:

National Center for Health Statistics. 2021.

DOI: https://dx.doi.org/10.15620/cdc:109050.

\section{Copyright information}

All material appearing in this report is in the public domain and may be reproduced or copied without permission; citation as to source, however, is appreciated.
National Center for Health Statistics

Brian C. Moyer, Ph.D., Director

Amy M. Branum, Ph.D., Associate Director for Science

Division of Analysis and Epidemiology

Irma E. Arispe, Ph.D., Director

Kevin C. Heslin, Ph.D., Associate Director for Science

For e-mail updates on NCHS publication releases, subscribe online at: https://www.cdc.gov/nchs/email-updates.htm For questions or general information about NCHS: Tel: 1-800-CDC-INFO (1-800-232-4636) • TTY: 1-888-232-6348 Internet: https://www.cdc.gov/nchs • Online request form: https://www.cdc.gov/info • CS326140 